\title{
English through the use of smartphone apps as motivation for students from the School of Tourism and Gastronomy
}

\author{
Enseñanza del Inglés a través de aplicaciones celulares como motivación \\ para los estudiantes de la Facultad de Turismo y Gastronomía.
}

Nestor A. Villegas-Virgen ${ }^{a}$

\begin{abstract}
:
With students spending up to $20 \%$ of their in-class time texting, emailing, and checking social media, it is no wonder the problem about smartphones in the classroom arises. This article presents results of a piece of research focused on the analysis and reflection of the smartphone applications used with higher education students in order to provide, as well as to improve, their results in departmental exams while they are studying English at a professional level.

The study took place over one semester of a curricular English course where smartphone applications were carefully selected and integrated into the current didactic units of the standardized institutional English program, with the purpose of finding, in the school of tourism and gastronomy, not only a solution, but a different approach to turning the problem into part of an updated methodology for the foreign language classroom.

The results of this research are expected to have a significant impact on the improvement of the methodology used by teachers at all the schools on our institutional English program with the effect that, once the teachers begin to implement the systematic use of smart phone applications in the delivery of their lessons, learners will hopefully perceive the English course as more relevant and meaningful and be motivated to achieve the expected results.
\end{abstract}

Keywords:

Apps, gamification, motivation, perception, technology, trends

\section{Resumen:}

Con los estudiantes pasando hasta el 30\% de su tiempo en clase enviando mensajes de texto, correos electrónicos y consultando las redes sociales, no es de extrañarse que surja el problema del uso teléfonos celulares en el aula. Este artículo presenta los resultados de una investigación centrada en el análisis y la reflexión de las aplicaciones de los teléfonos celulares utilizadas con los estudiantes de educación superior para proporcionar, así como para mejorar sus resultados en los exámenes del departamento mientras estudian inglés a nivel profesional.

El estudio consistió en un semestre de un curso de inglés obligatorio en el que se seleccionaron cuidadosamente las aplicaciones de los teléfonos inteligentes y se las sumergió en las actuales unidades didácticas del programa de inglés institucional con el fin de encontrar, en la escuela de turismo y gastronomía, no sólo una solución sino una forma diferente de convertir el problema en una metodología en el aula.

Se espera que los resultados de esta investigación tengan un impacto importante en la mejora de la metodología utilizada por los profesores de nuestro programa institucional de inglés entre todas las escuelas; de manera que una vez que los profesores consideren aplicar las aplicaciones de los teléfonos inteligentes en su desempeño, los alumnos puedan percibir el curso de inglés de manera más significativa y obtener los resultados esperados.

\section{Palabras clave:}

Aplicaciones, gamificación, motivación, percepción, tecnología, tendencias

\section{INTRODUCTION}

Language is the most effective and sophisticated way of conveying our thoughts and feelings to others. English as a
Second Language (ESL) has achieved the acknowledgement of being considered a universal language and this recognition has given rise to different opinions regarding what we, as teachers, must focus on when teaching. Additionally, technology is also

${ }^{a}$ Nestor A. Villegas Virgen, Universidad de Colima, Colima, https://orcid.org/0000-0002-0684-666X, Email: villegas_nestor@ucol.mx 
becoming more widely used day by day, with the result that younger students (or generations) tend to use it automatically, without seriously considering when it is truly necessary.

For a long time, the object of study in language classes has been the language itself. Descriptions of language derived from the perceptions and research of linguists; traditional grammars such as: transformational-generative, structural, functional and discursive analyses, etc. found their pedagogical translation in the teaching of specific areas of the language (for example, the elements of a sentence, and the analysis of texts). These descriptions, alongside the conception of the learning process as habit formation, rule acquisition, active information processing, emotional experience, have resulted in a variety of methods and approaches for teaching a foreign language.

Grammar can be seen as "the study of words and the rules for their formation and their relationships to each other in sentences; the rules themselves; speech or writing judged as good or bad according to these rules" (1980:282, Oxford American Dictionary). So, grammar is undoubtedly important in the production of any given language, nevertheless, in our institutional context (the school of tourism and gastronomy), there has been a tendency for teachers to use terminology which is far too formal, when trying to explain a specific set of rules to their students. This has tended to cause difficulties in understanding the functioning of certain grammatical rules and structures for many students.

As Jeremy Harmer (2007) stated, "Teachers tend to lean on meta-language when approaching grammar, courses have stuck with grammar and $90 \%$ of methodologies rely on it as the main means of conveying knowledge of a foreign language". However, immersion approaches do not consider grammar as the core of the learning process, and have often yielded better results, when learners come to use the language in real contexts. This is mainly with approaches such as TBLT (Task-Based Learning Teaching) as Long, M. (2015) stated and where he also emphasizes the differences between second language acquisition (immersion) and second language learning (instructed)

On the other hand, vocabulary is "a list of unfamiliar words with an explanation of their meanings, accompanying a piece of specialist or foreign-language text." (1980, Oxford American Dictionary). So, nowadays, vocabulary is introduced and given to students in small chunks of information in relation to a specific area. According to Harmer (2007), "memorization has traditionally been the most efficient way of making students keep in mind and remember words whenever necessary for them". In spite of this, he mentions that "vocabulary is now just a way of memorization, but it has to be memorable to students in order to reach acquisition of those lists".
Both grammar and vocabulary are similar when it comes to teaching because they need a higher level in cognitive processes to complete the learning process, which means all activities used to acquire one or the other must be presented as a sequence by the teacher so students can relate the rule with the corresponding vocabulary from the lesson. Also, they both need one another, you cannot structure sentences without vocabulary, but you cannot learn vocabulary with no structure to fill out (Shin, \& Crandall, 2014)

Some of the differences between vocabulary and grammar in the context of an ESL class are as follows: vocabulary is more significant than grammar, because "communication is carried out through the use of words, and people can understand ideas even though words are placed in ways which are not the most common for native speakers of the language" (Richards, C. Jack, \& Rodgers, S. Theodore 2001:85). This is why all activities implemented in the creation of lesson based on some smartphone application needed to include, primarily vocabulary so the cognitive process can be helped to reach meaningful learning.

In order to start talking about motivation we need to know what it is all about; "motivation" means "to move" from Latin root "movere". Therefore, the study of motivation is the study of action. Today, most theories that talk about motivation link beliefs, values and goals to action, but in this article, I will focus on motivation as it relates to developmental psychology and education. Weiner (1992) says that the different theories of motivation come from different intellectual traditions, and here, I decided to focus on motivation and the expectations my students may have so I could come up with better implementation for the smartphone applications I intended to use throughout the semester.

There are several theories that focus primarily on the expectation of individuals' beliefs about the competence and effectiveness they have when carrying out a planned activity, in the same way that, they refer to expectations of success. "Failure and knowledge of the process that has been carried out to achieve objectives and why it has failed or been successful. This ideology is associated with certain attitudes and questions that contribute positively to better performance and thus generate interest and commitment to continue working in more difficult activities" Bandura (1997). That is why it was important for me to deepen my knowledge of what could motivate my students and how I could match their needs as well as beliefs

Bandura (1997:55) proposed a cognitive-social prototype of motivation that focuses on understanding an idea of efficiency, "i.e., the idea of what you plan to do is analyzed and therefore the task is performed to achieve the goal and, similarly, the human agency that is defined as the ability of each individual to act independently and make his or her own choices freely." 
Bandura determined that "self-efficacy was determined as the motivation and resolution that individuals possess in their ability to plan and then execute an action plan to solve a problem or perform a specific task". He identified it as a multidimensional construct that varies in strength, inaccuracy and degree of difficulty. As a result, each person knows his or her strengths and weaknesses when performing a specific activity, for example, there are different types of people who believe that they have the ability to do everything they set out to do in a variety of circumstances, while others believe that they are close to being effective; and some believe that they are able to use their sense of effectiveness in even the most difficult tasks, while others believe that they are effective only at performing easy tasks.

With respect to the above, the author points out that "the theory focuses not only on how adults and peers influence individual learning, but also on how cultural beliefs and attitudes influence how teaching and learning is delivered". It should be noted that Vygotsky's socio-cultural theory is one of the foundations of constructivism, which means that children cease to be merely passive recipients and become the architects of their own knowledge and schema, of information they receive from a provider. Consequently, Vygotsky stated that the basic concept of socio-cultural theory is the human mind and how this measure, "i.e., the mind is not in accordance with traditional and generalized norms, and also inferred that humans do not act directly in the physical world. but depend on tools and work activity, which follows us to change the world, and with it, the circumstances in which we live" (cited in Lantolf, 2007:63).

Nonetheless, no methodology has found its basis in how to get students to be willing to acquire everything planned by their teachers nor the motivation to cope and want to be in English class, So that, in an area where technology is at every inch of the classroom we, teachers, must not penalize it nor punish it because that will cause a battle field where technology has paved its way to the winning place. Thus, we must be friends with it and use it not against us but alongside with us.

\section{METHODOLOGY}

Following the methodology used by Hernández Fernández and Baptista (2014), the research reported in this article was designed and implemented as a case study, with a qualitative approach. It was implemented by means of detailed observation of two control groups with the same curriculum as well as the same language level carrying out various activities during the semester August - January 2019-1. This section presents more detailed information.

Initially, there were two groups, one from 3rd semester and the other from 5th semester, with a total of 18 and 23 students respectively, where the participants ranged from 18 to 21 years of age at the Faculty of Tourism and Gastronomy, Las Garzas campus of the University of Colima. Due to the nature of the study and with the hypothesis stated about generating a significant improvement in the students' results in the institutional examination, it was decided to use, in one group, a methodology mediated by smartphone applications and in another group to implement the usual departmental methodology, without including any use of technology. All groups had achieved the same level of English (A2+ according to the CEFR) and were in parallel courses, therefore, they would all study the same course content. For the purposes of presenting the results in this article, the group which was taught using the traditional methodology will be known as "Group A", and the group which was taught using the methodology mediated by cellular applications will be described as "Group B".

\section{APPROACH PROCEDURE}

In order to apply this suggestion of methodology, I had to consider my own steps to follow so that I could truly analyze my own planning; the steps followed were:

1 Observation of students' needs: This step was carried out with the very first interview students were asked to attend. All of this took place during the last weeks of the semester previous to the one where the new approach was supposed to be applied. This step was meant to gather students' attitudes, beliefs, personality, and academic needs with group games interventions, warm-up activities, and icebreakers

2 Apps selection: based on the information collected in the first step, I had to skim for applications which matched my students' needs and personalities

3 Lesson planning: Finally, once I had found what I needed the most for my students to experience brand new classes, what I had left to do was planning my lessons as normal. The only difference was, that the core of the planning was using the applications I thoroughly selected.

In every single session I had with my students, at least, one activity was planned in order to have more valuable and reliable data on how the use of smartphone activities could impact my students' language acquisition.

You will find the list of applications I used for this study, so you can analyze them by yourself and see if they or any of them suit you, the activities used were: vocabulary presentation, vocabulary review, grammar review, grammar analysis, structure in context, expression memorization, and speaking triggers.

\section{INSTRUMENT DESIGN}

Three instruments were used for data collection:

1) A structured interview divided into three separate stages was implemented. The first part comprised a diagnostic 
interview (used to gather information about expectations, beliefs, needs, and what students' academic tendencies towards English class were); in the middle of the semester as a follow-up interview (used to gather information about how students were engaging with the new lessons and activities through smartphone application); and at the end of the semester as a result interview (used to collect information about the comparison of the starting expectations and beliefs and the final thought of their English class).

2) A field diary was kept by the teacher in charge of the groups (in this case the researcher), and daily notes were made on activities and processes from the lesson planning based on smartphone applications. In addition, it included a guide of observations and reflections of the teacher on his students' reactions, performances and participations in class for a second time to compare them with the results obtained by the interviews.

Finally, an institutional knowledge test of English as a foreign language was implemented, which aims at the key skills and knowledge that students should achieve at the end of their semester on an upward path to graduation. This exam is designed by the authorities in charge of the University English Program (PUI, the Spanish abbreviation) and is taken at the end of every semester.

\section{Institutional Curriculum Topics Level B1-}

\begin{tabular}{|c|c|c|}
\hline $\begin{array}{l}\text { Grammar } \\
\text { Content }\end{array}$ & $\begin{array}{l}\text { Professional } \\
\text { Content }\end{array}$ & $\begin{array}{c}\text { Communicative } \\
\text { Content }\end{array}$ \\
\hline $\begin{array}{l}\text { - Verb tense } \\
\text { review: } \\
\text { Simple } \\
\text { present } \\
\text { tense vs. } \\
\text { present } \\
\text { continuous } \\
\text { tense } \\
\text { - Simple past } \\
\text { tens (regular } \\
\text { and } \\
\text { irregular) } \\
\text { - Present } \\
\text { perfect tense } \\
\text { - Future with } \\
\text { will } \\
\text { Will+ time } \\
\text { clauses } \\
\text { Infinitive of } \\
\text { purpose }\end{array}$ & $\begin{array}{ll}\cdot & \text { ON TOURS } \\
\text { - } & \text { BUSINESS } \\
\text { TRAVEL } \\
\text { - TOURIST } \\
\text { INFORMATION } \\
\text { SERVICES }\end{array}$ & $\begin{array}{l}\text { - } \begin{array}{l}\text { Asking for } \\
\text { advice }\end{array} \\
\text { - Asking for an } \\
\text { item } \\
\text { - Giving a } \\
\text { warning }\end{array}$ \\
\hline
\end{tabular}

Figure 1 : Institutional Curriculum

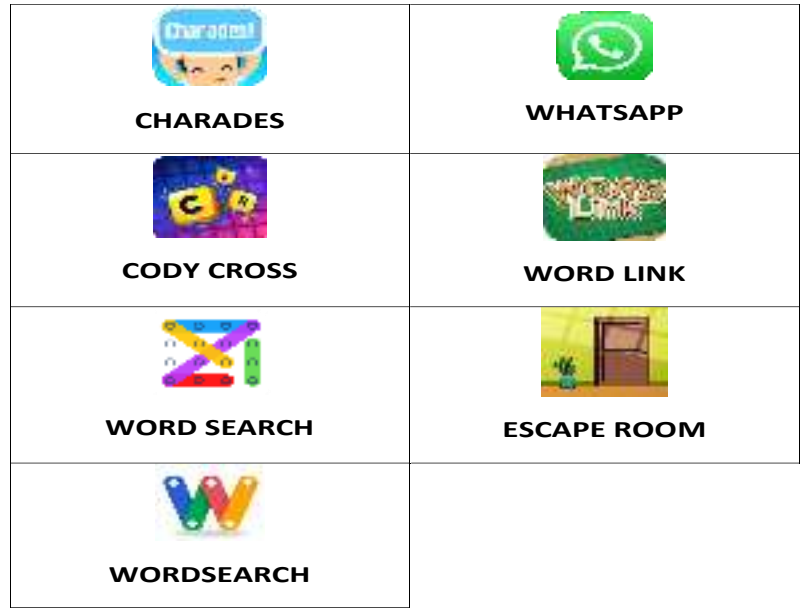

Figure 2: The applications used in group B (control group)

\section{RESULTS AND ANALYSIS OF DATA}

Finally, as a result of an exhaustive investigation as well as a long, controlled, and effective analysis of the answers obtained both in the interviews and in the numerical results of the institutional examination, it was possible to observe that both groups followed different methodologies, which led them to develop in a different way as well as it was possible to verify that the motivation in each group was different which determined a very differentiated development of the competencies required by the university English program.

In this way we can observe the results of the advanced English exam applied in an institutional way at the time that both groups started the 2019-1 semester

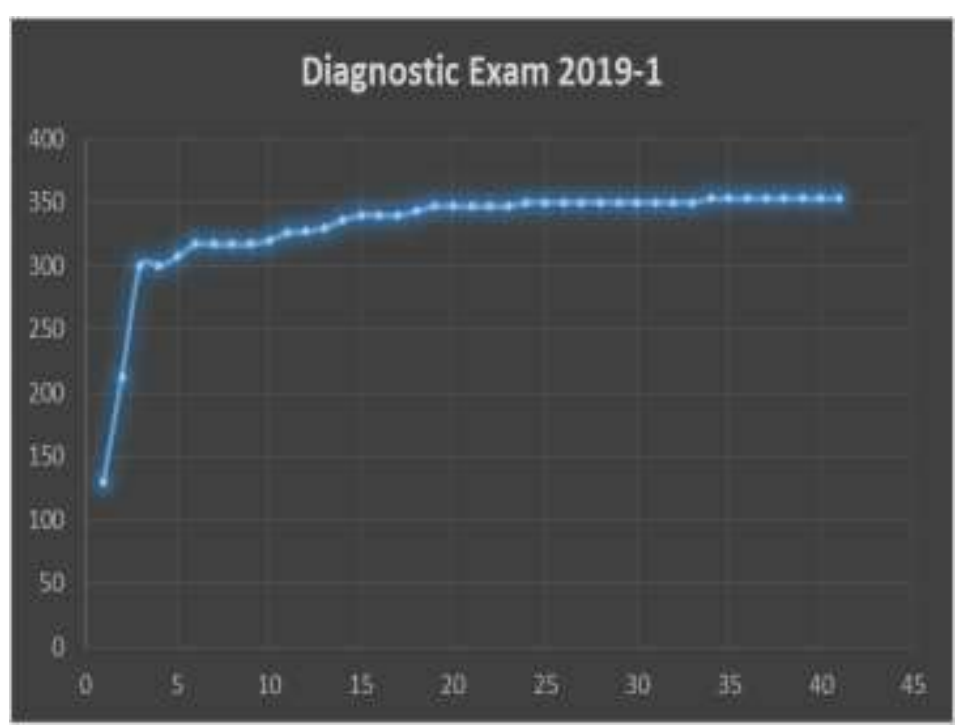

Graph 1: Initial results

Similarly, we can observe the results of the same institutional examination at the end of the 2019-1 semester, and we can see a 
very significant difference in both groups, with group B achieving the best results.

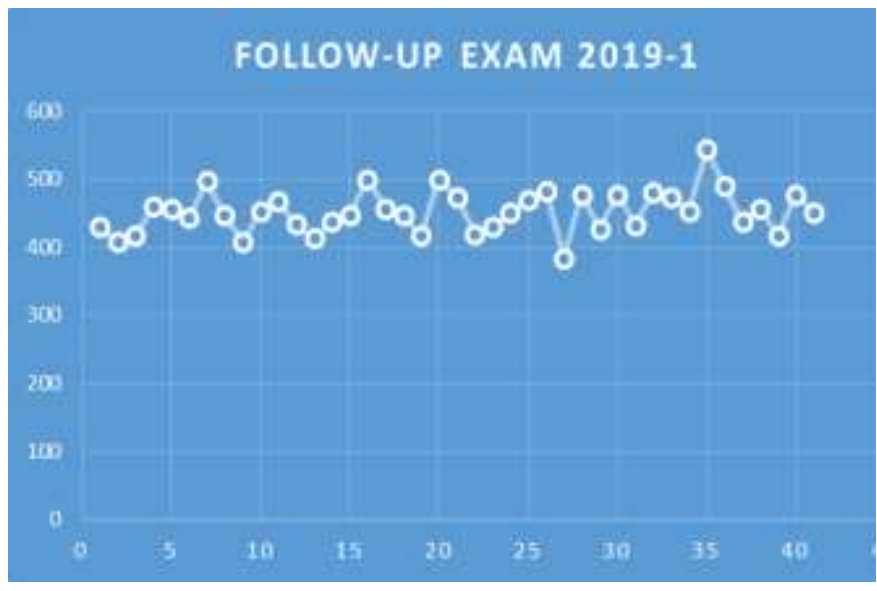

Graph 2: Final results

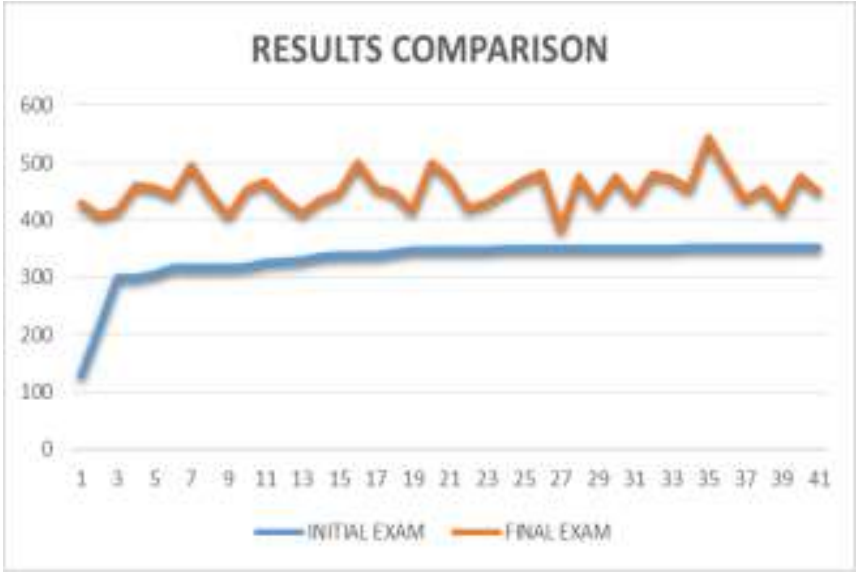

Graph 3: Comparison of results

The activities implemented throughout this case study proved to be viable, possible and productive in order to teach both theoretical and practical knowledge of topics required by the institution, thus directly affecting students' perception and motivation. This allowed us to answer the research question generated at the beginning, which stated the following: Will the use of smartphone application in English class boost students' language level?, concluding that the implementation of activities based on the use of smartphone applications for the development of English classes in our institution helps to strengthen the competencies desired by the institutional exam implemented at the end of each semester, thus gaining confidence and value to produce the language.

The students in group B were proactive and participative with regard to the strategies presented. Likewise, there was mutual support among the students, due to the fact that some students had different problems, since when carrying out the activities they took longer to complete or did not achieve the objective of those activities so that the little more advanced students or those with a greater aptitude for English intervened with their companions to help them understand the activity to be carried out.

The research found that most of the activities mediated by smartphone technology within the classroom or use of the target language through playful applications in front of an audience proved to be very favorable, attractive and accepted by all students, thus allowing greater participation and more productive investment of time in the classroom. These applications were the ones listed above since I had to stay with the same ones during the whole research.

For the students who participated in this research in Group B who had a more introverted personality, the methodology implemented in their classroom developed a change at the end of the first month, when the teacher observed a completely opposite type of behavior and opinion to the one identified at the beginning of the semester which means that smartphone applications in the classroom motive, even introverted students, to participate and speak more since they are engaged with what it is being presented. The students themselves confirmed these observations, since in the results of the diagnostic interview and the final interview a change could be observed in the results referring to the following questions:

\section{Do you consider role play activities to be attractive to you?}

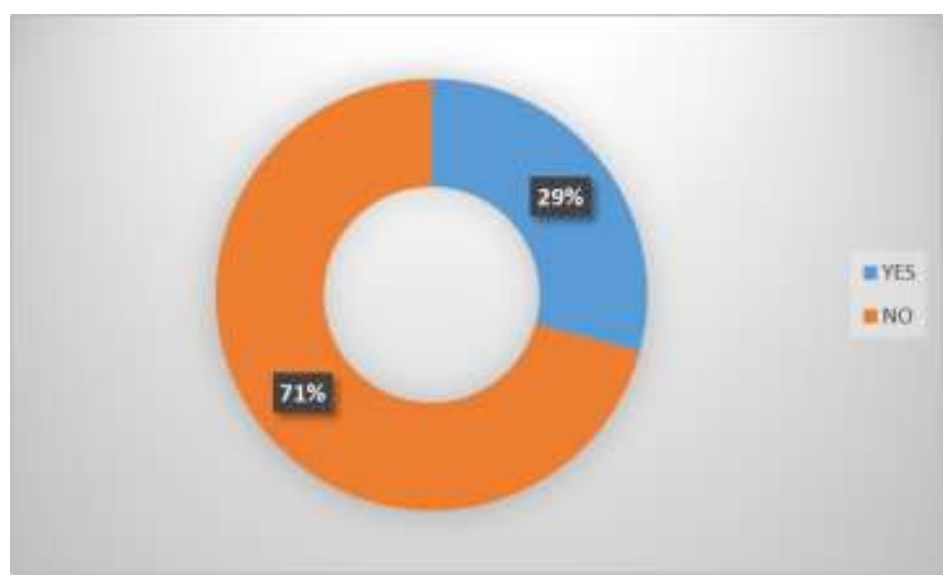

Graph 4: Diagnostic interview, Question 5

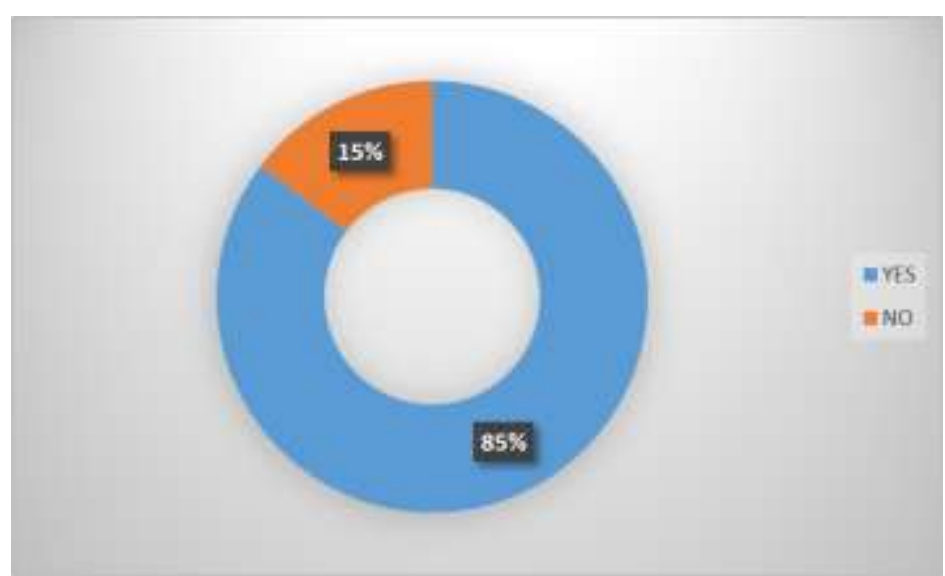


Graph 5: Closure interview: question 5

What's the first thing that comes to your mind when you think about your English class?

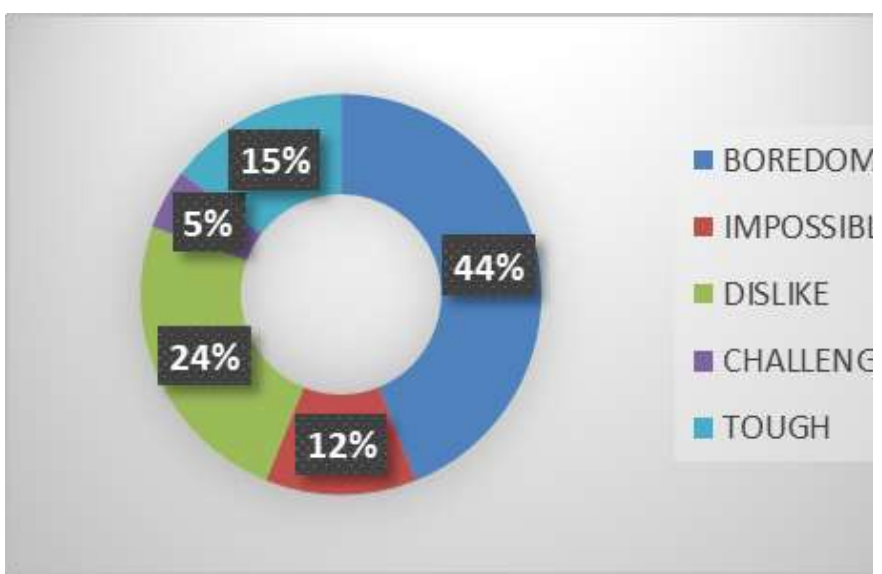

Graph 6: Diagnostic interview: question 1

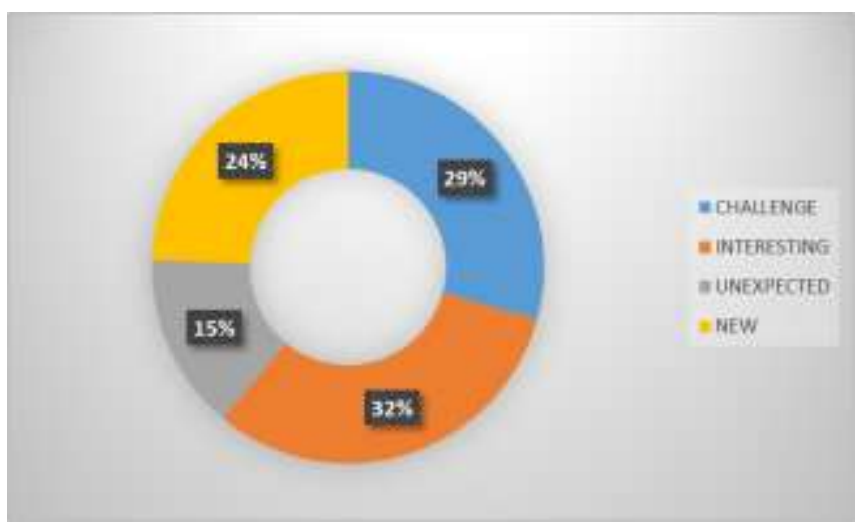

Graph 7: Closure interview, Question 1

What percentage of the time do you consider yourself to be involved in your English class?

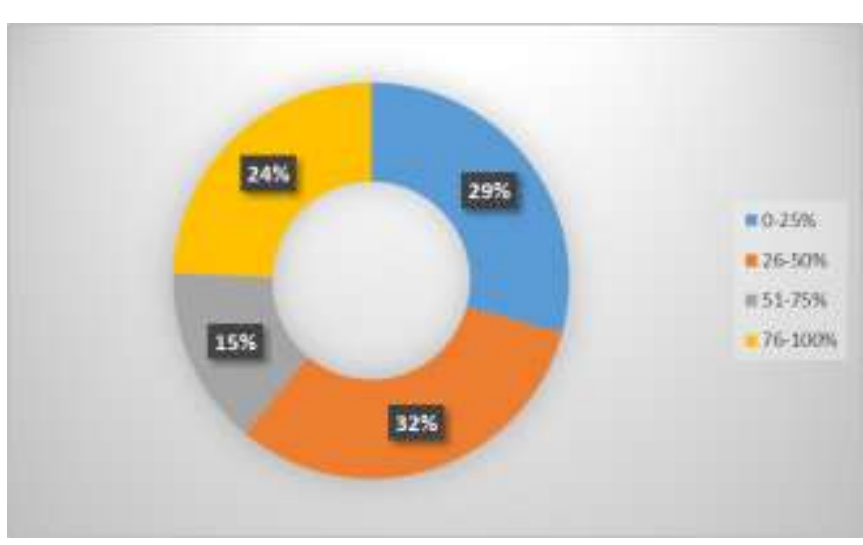

Graph 8: Diagnostic interview, Question 10

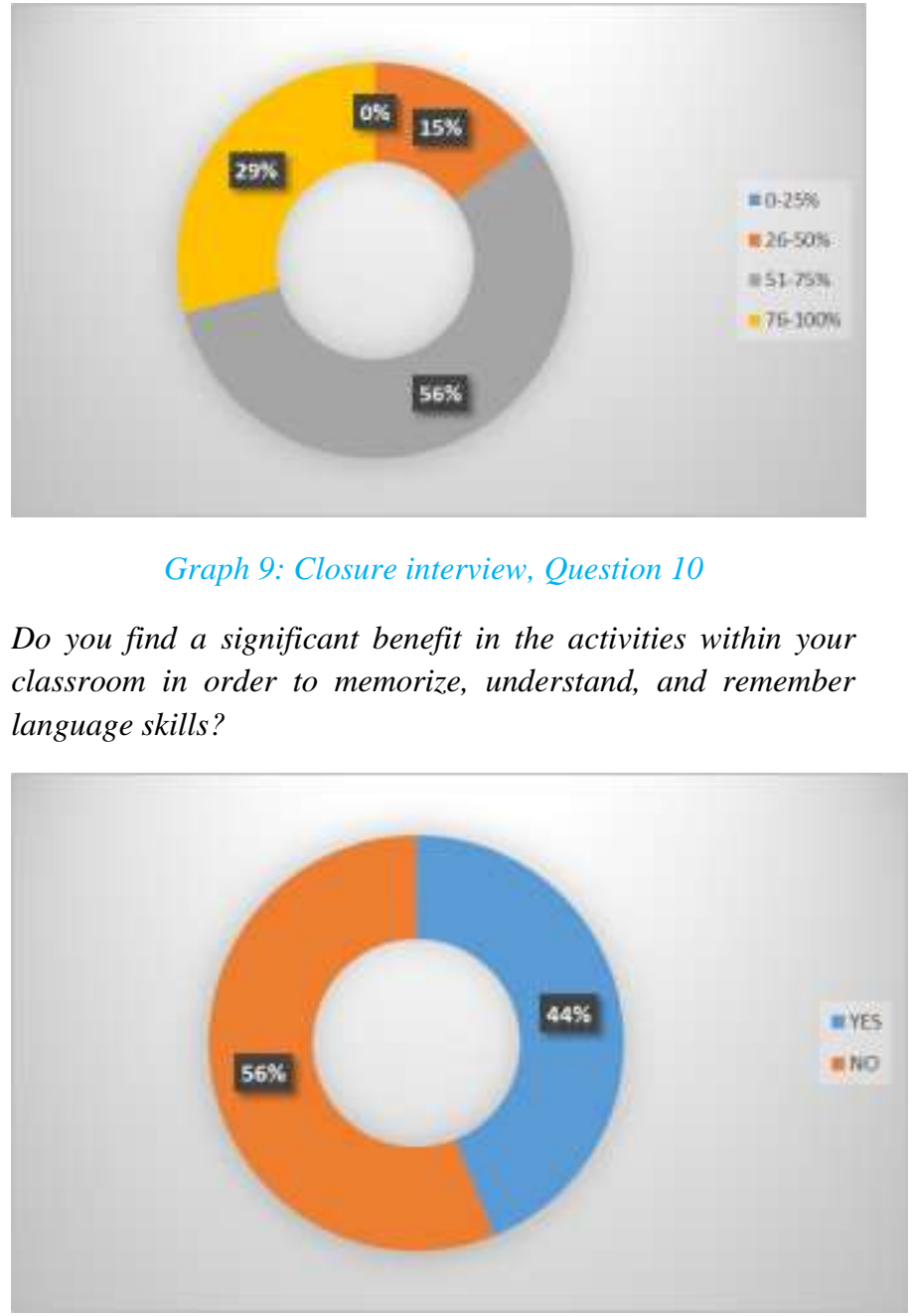

Graph 10: Diagnostic interview. Question 12

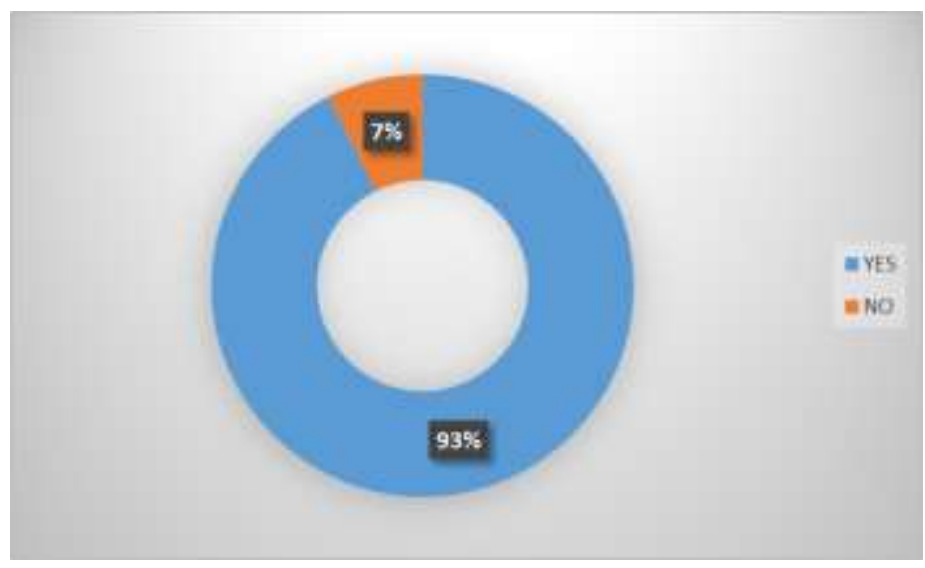

Graph 11: Closure interview, Question 12

The activities (strategies) helped learners to have more confidence in themselves and in the language, which gave them the courage to express themselves orally and to understand the use of different grammatical structures, in a greater part being able to carry out exercises which they previously found 
difficult.

Knowing the grammar and the communicative processes that this entails through the use of smartphones and funny applications promotes and facilitates the early understanding of concepts and words since the positive transfer of mother tongue and target language works as a natural and known support for the new learning acquired during the course.

Within this methodology mediated by smartphone applications allowed, likewise, that the positive interferences (words, or information students grasp or get as input from their native language) were well used to generate knowledge while those ones negative were corrected as well as stored in order not to make mistakes.

The topics being involved in recreational activities by means of the use of technology resulted in collaborative support and creative a helpful platform to be able to overcome their fears towards the language and they managed to improve their fear to people thanks to the activities that entailed performance, while other introverted students concluded that they were not able to carry out this type of activities since they find it not only difficult but "impossible" (according to what some of them commented) to perform in front of their companions. However, they were students who developed better results simply by being visual and learning through visual analysis of their environment. This is because the information gathered from the field diary made it clear for the qualitative analysis since I had had the same groups one semester before

\section{CONCLUSIONES}

The concept of self of the person includes particular characteristics, among which stand out certain values acquired over time and displayed through their approach to classmates, almost at the same level of language proficiency as themselves.

Some of the characteristics which successful learners seemed to display increasingly during the study are: autonomy, sociability, curiosity, responsibility for initiative, punctuality, resilience, critical thinking, taste for learning, perfectionism, pedagogical skills. These stood out as being contrary to the previous characteristics, identified during diagnostic interviews, such as the lack of grammatical knowledge, introversion, shyness, waste of resources available for the subjects and also the lack of use of key moments when the target language could be used.

This information was considered and gathered with the interviews and the performance students developed in every single class they were in. Though the characteristics previously described were observable from the students I taught for a whole semester, it is not meant to generalize since we must know every single student, and group of students, have different needs for them are immersed in a totally different context.

That is the reason why, before trying to apply any planned activity derived from a smartphone application you should closely analyze your students in order to get a better perspective of what characteristics they show before you apply such activities in order to plan your lesson and have a successful use of smartphone applications.

The concept of applying activities based on smartphone applications involves both attitudes and actions, including: 1) the autonomy of students, 2) their active role in the classroom, and 3) the teacher's general approach to the subject.

The needs your students may have can be clearly identified by constant observation, as they bring with them their personality already created and influenced by the pedagogical methodology of a common English class.

Although personality dominates their way of learning, once they are presented with a different methodology, as well as they see that their interests are taken into account, creates a better learning environment for students, helping them acquire new knowledge and foster what they already know in order to continue their second language learning process

It was found that the fear of teasing was reduced among the students, as the activities sought to develop mutual support (as it is explained with the Zone of Proximal Development by Vygotsky) so that together they could improve and correct their mistakes by observing the group support they gave each other.

We can say that it is now possible to learn more about teaching strategies for teaching English at the university, particularly in the faculty of tourism and gastronomy. This enrichment of the literature is modest at the international level, but it is of considerable importance at an institutional and national level.

Thanks to the results, it is now possible to affirm that we know what is happening with regard to the principled use of phones to support learning, that this knowledge can have positive effects in educational environments related to the teaching of languages, specifically English, and enabling teachers to help our students reach their goals concerning communication in foreign language, and for teachers to reach the institutional goals set every semester by the designers of the University English Program.

It was found easy to use group activities in which the act of speaking (producing language in the target language) was done in groups and leaving aside the individual evaluation.

Mimicry and bodily expression to support explanations as well as the performance of the activities are shown to be more beneficial to the subjects thanks to the visual capacity of the latter to understand the instructions given in the target language.

We can therefore conclude that, redesigning Language Education in higher level such as university, is essential to fight 
back the weaknesses, and problems our students face based on their cultural background, because theories about language learning and teaching were made and answered problems from a specific date in time, nonetheless, those same theories must not be thrown away but rather rebuilt in order to match our present time and its challenges.

Let us never forget that our students have grown up in a fast and different range of cultural behaviors, which continue to change drastically as time passes. Addressing our students as "XXI century students" may be ambiguous nor even $100 \%$ accurate for this fast-growing area of philology and behavior we have covered so far. So, applying the use of smartphones, apps, and technology loved by students may be different from context to context but we can assure that it can lead to success in a world where language education must constantly be renewed faster than ever.

\section{REFERENCES}

[1] Álvarez-Gayou Jurgerson, J. L. (2009). Cómo hacer investigación cualitativa: Fundamentos y metodología. Barcelona, España: Paidós Educador.

[2] Benalcázar, M., Caizaluisa C. F., \& L. V. (2019). Conciencia lingüística-cultural en el desarrollo de la destreza oral en el idioma inglés. Universidad central del Ecuador, 172.

[3] Cabrales Vargas, M., \& Loaiza Trujillo, N. (2018). Globalización, internacionalización e interculturalidad: Una mirada desde la formación del docente de lenguas extranjeras. Revista Internacional de cooperacion y desarrollo, 225.

[4] Gaonac'h, D. Acquisition et utilisation d'une langue étrangère. $1^{\circ}$ edición. Paris, Francia: Hachette. 2011

[5] Gass, S. Slinker, L. Second language acquisition. $3^{\circ}$ edición. London, UK: Routledge. 2008

[6] Harmer, J. Jeremy. The practice of English Language Teaching ( $4^{a}$ ed.). México, México: Pearson. 2007

[7] Kees de Bot, W. Verspoor M. Second Language Acquisition an advanced resource. $2^{\circ}$ edición. London, UK: Routledge. 2006)

[8] Lagarde, C. Conflits de langues, conflits de groupes. $1^{\circ}$ edición. Paris, Francia: Le Harmattan. 1996

[9] Maturana, H. R., \& Varela, F. G. (2003). El árbol del conocimiento: Las bases biológicas del entendimiento humano. Santiago de Chile: Lumen

[10] Michael O’Mally, J. Uhl Chamot, A. Learning strategies in second language acquisition. $1^{\circ}$ edición. Cambridge, UK: Cambridge University Press. 1995

[11] Navarro, D. Dunia, \& Peñeiro, M. Milagro. Didactics Strategies for Teching English (Ed. rev.). Costa Rica, Costa Rica: Universidad de Costa Rica. 2012

[12] Richards, C. Jack, \& Rodgers, S. Theodore. Approaches and Methods in Language Teaching ( $2^{\mathrm{a}}$ ed.). Cambridge, United Kingdom: Cambridge University Press. 2001

[13] Shin, K. Joan, \& Crandall, J. JoAnn. Teaching Young Learners English (Ed. rev.). Boston, USA: National Geographic Learning. 2014

[14] Widdowson, H.G. Linguistics. $1^{\circ}$ edición. UK: Oxford University Press. 2007

[15] Long, M. (2015). Second language acquisition and task-based language teaching. Malden, MA: Wiley-Blackwell. 